\title{
Depiction of Society Through the Weapon of Art
}

\author{
Shalini Sharma and Nirmal Sharma \\ Department of English \& Foreign Languages, SRM Institute of \\ Science and Technology, Delhi NCR Campus Modinagar, India
}

\section{ABSTRACT}

The purpose of art is not only to entertain and for fun but for reformation, purification and renovation. Literature is one of the most appealing forms of art. Literature is decorated by the different colors of society in its real manner. With artistic approach, an artist or a literary figure is always busy to portray the real image of society through his art or literature. A massage can easily be forwarded to a huge number of public through literature. This society has been divided into different parts, sometime on the basics of caste, creed, religions, knowledge and education. This division has influenced the mentality of the people who began to consider them superior, higher and over smart and they treat others as inferior. So this way of thinking should be changed. Human being is the creation of God who has prepared everyone else equal with equivalent powers and rights. People should have same regard and honor for others. First they should try to change their thinking and then to others. Literature plays a very imperative role in this regard. An author can interconnect with the emotions and sentiments of the people automatically only by his works. He can enter the heart of anyone else only by his creation. He can enlighten the fire of reformation in thoughts, feelings and actions. He can bind anyone else to change. Having this purpose, an attempt has been made in the present research paper to undertake a comprehensive study of Indian society in the fictional works of Bhabani Bhattacharya, Mulk Raj Anand, Robin Sharma, Priya Kumar and many more great authors.

KEY WORDS: RENOVATION, EQUIVALENT,EMBELLISHMENT, RUFFIANS, SPONTANEOUS, PREVAILS, ETC.

\section{INTRODUCTION}

Art always plays a part of mediator between the society and the audience. Literature, paintings, movies, music, sculptures all are the different forms of art. No doubt they are different in features but they are having the same mission that is to portray the reality of society. All these forms of art have a deep concern that the people of the society should be aware of all the facts, problems; hardships that are prevailing in the present scenario. Literature is the mirror of society. It is the main concern of every literary figure torepresent anactual society by his creation that is called a work of art. The writer should try his level best to make his writing a valuable piece of work so that it may preach ethical values to all its readers. But it is also a fact that these virtues should not be presented

Biosc Biotech Res Comm P-ISSN: 0974-6455 E-ISSN: 2321-4007
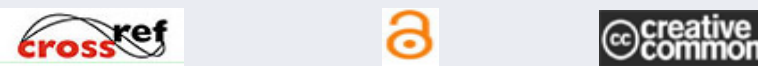

Identifiers and Pagination

Article Information

Year: 2021 Vol: 14 No (8) Special Issue

Pages: 208-210

Received: $09^{\text {th }}$ June 2021

This is an open access article under Creative

Commons License Attribn 4.0 Intl (CC-BY).

DOI: $h$ ttp://dx.doi.org/10.21786/bbrc/14.8.48 in an imposing and didactic manner. Rather a kindle of desire to reform should be awakened automatically.

Literature Review: Bhabani had his own views and ideas on the nature and value of fiction which is undoubtedly, a part of art. He wrote literature for social interest and benefit. He formed his own principles for his creative writings after studying Marxist Ideology, John Steinbeck, Rabindranath Tagore, Mahatma Gandhi, and Nehru, other well-known personalities and historical figures and undergoing foreign trips from time to time. He firmly held that the real motto of an art and literature, should not be to give only pleasure and entertainment to its onlookers and readers, rather it should carry a definite purpose along with it which should be directly connected with the society of human beings. He remarks "I hold that a novel must have a social purpose. It must place before the reader something from the society's point of view. Art is not necessarily for art's sake. Purposeless art and literature which is much in vogue does not appear to me a sound judgment." (Bhabani Bhattacharya: His Vision and Themes, 121)

Bhabani disapproved, as a result, of the dictum of 'Art for art's sake'. Instead he propounded his own theory, 
'Art for life's sake'. He thought that the work of art may be any branch of literature, should not only fulfill artistic requirements and jovial standards, rather some morality should be rooted in it as can be discerned from the undernoted lines. "The ruffians want to end untouchability. You (villagers) won't approve of that. But who are you to stop a world force? All untouchabilitythere are different sorts under different labels almost everywhere-is being brought to an end. Mankind has a new charter of equal rights for all."(Music for Mohini, 78)

Bhattacharya advocated that an artist or writer should be much careful while expressing his views in his work, because he was not going to do it only for work's sake, rather he was going to preach, to teach or to leave some valuable morals in it for society. They should be spontaneous and arise from the author's inner self. Bhattacharya affirms."I have not believed in writing for the sake of writing. I seldom planned a story structure. Each story grew in my subconscious mind as it were. When it had grown enough, I had to give it physical form." (Contemporary Novelists in the English Language, 52)

Consequently, an ingrained purpose is found in the work of Bhabani Bhattacharya. All his novels are filled with social concern. They deal with Indian social life. He has touched all the parts of India, rural as well as urban. They connect not only the whole country but also the real feelings of their countrymen; they may be virtues or vices. The main mission of this function is to reveal to Indian society that there are a lot of short-comings and social problems, prevailing in the society and people should recognize them with the help of Bhabani's novels. They can realize their faults and should try their level best to remove them from Indian Society. That is why; his novels not only narrate a story to the readers but also convey some important moral lessons to them. The characters portrayed there touch their emotions so that they may receive didactic lessons from them. His fictional works hold a mirror to Indian society. Bhabani Bhattacharya firmly holds that the real goal of novel is to create awareness in society about its imperfections. It goes without saying that literature affects the thoughts of men a lot and Bhabani believes that it is the strongest instrument to remove men's vices by pointing them out to them. India got her freedom and it was the right time to improve Indian's mentality and create faith in sincere work and labor and it could only be possible by way of literature. Only then India could be counted as a strong nation free from all vices. At one place he himself remarks

"Brothers, now that we have freedom, we need acts of faith. Then only will there be a transmutation. Friends, then only will our lives turn into gold. Without acts of faith, freedom is a dead pebble tied to the arm with a bit of string, fit only to be cast into the river."(A Goddess Named Gold, 303) Another important belief that Bhabani holds is that art is not an 'escapist romanticism'. He opines that a real and social writer should not be remote or detached from reality.

It means that the subject-matter of the novel should be connected well with the life around the novelist. He should not try to escape himself from the real atmosphere of the society. He can never be out of it, because with the wings of fantasy, he can fly only for a short while after that he has to return into reality. As a result, a creative writer like Bhabani Bhattacharya always delineates the social realities in his novels with his sharp sensitivity and keenly discerning power. The interpretation of real life, that is why, is the subject matter of Bhabani's novels. Mark what he himself says. "There are dangers in tendentiousness, but they are matters of technique. Art is not a pulpit or platform from which one may uphold and denounce. Further, literary art is not black and white. The most heroic character must have his feet on common earth and the dastardly villain, even more difficult to create, needs to be redeemed by the "human touch." Otherwise, credibility is lost. The willing suspension of disbelief on the reader's part is withdrawn."(Perspectives on Bhabani Bhattacharya, 31)

Bhabani Bhattacharya paints the portrait of miserable livelihood of Indians in the genuine colors in his writings. He examines the sufferings of the common people only to cure their ills in this world of hypocritical people. The working class people worked hard to make both ends meet. With their limited sources of income, they toiled a lot to feed their family. But sometimes they even failed to do so. They labored all through the day and then got three or four rupees which had the value of only one rupee. The condition of working class people was extremely miserable. Mills products had taken the place of their simple home production goods. Material and articles, on which they had worked very hard, had no value, because the people who had money preferred to purchase the things manufactured in mills. So their rough and rude things had no attraction for customers in the market.

Further still, heart rendering and stunning information that Bhabani Bhattacharya gives in his works is that a poor man had no value of his body before but after his death. He became a great source of income for someone else. The novelist thinks about the profession of doctors who are considered just like God as they can give some relief to the suffering humanity. But doctors, as a matter of fact, were totally after money. There was no beating heart in their bodies. People were highly amazed to find out that the doctor was not a relief-giver; rather he came there for his profit. The heartless doctors needed skeletons of the dead bodies for dissection. They sent them to other countries and secured good price for them.

Analysis: According to Bhattacharya, novel is that part of literature in which the writer can express his innermost urge which is the consequence of his inmost sensitivity and keen power of observation. The things which are happening around him affect him and then with his 
extra ordinary sensitivity, he creates them in his novels. With the help of his emotional urge and sensitivity, he feels his own existence in his novels and this is what happened with Bhabani Bhattacharya. He can never be far from reality. His own personality, thinking, trials of getting rid of social problems, his emotions are always present in his novels. He never tries to escape from the hardships of society.

The same concept of suffering and hardships can be realized in 'Untouchable' by Mulk Raj Anand who also presented the society in its real manner. His novels, Untouchable, Coolie are the best examples of it. For him, every writer has a great power in his pen that can expose the vices, follies of the society. By this weapon of writing, a writer can convert a man into human being. The pathetic condition ofBakha in Untouchable is hearttouching that it canbe bound to think that these people do not have the right to live respectfully in society. Untouchables have to tolerate so much mental agonies due to the upper class. So much humiliating, one will feel if someone is going to address in such manner, "Get up, ohe, you Bakhya, One son of pig! ...... Are you up? Get up, you illegally begotten”.(Untouchable,5)God has made everyone equal, without any special marking and any class. It is we people who has made these classes and such useless systems. Nobody is big or small by birth or by religion rather we should try our level best to be big by our deeds. Everyone should have such humanitarian approach.

Each and every author has dreamt for strong, united, prosperous and peaceful nation. Each has drawn and depicted India before his readers with a hope that they will leave no stone unturned to develop and shape their country well in the time to come. India will be anaffluent country one day. This hope and dream they are having in their heart. No doubt, with the advancement of knowledge and education, the mindset of the people is getting changed. Actually they should understand the need of internal purification. We are having a lot of dirt inside us. So internal reformation is mandatory. It is very easy to clean the dust from outside but it is very difficult to change the attitude of the people. For it, there should a desire to be changed and it will not be wrong to say that now the people are feeling the need of it that is why they are turning towards meditation, exercise and yoga classes. Human soul wants peace and internal satisfaction. Human body shouldrealize this thrust and should do the work for it. People should understand the main root of their existence and should do efforts for their upliftment. Everyone should understand that we are the destiny maker.

It is we who design our own luck. We decide the limits of our sorrow and the boundaries of happiness. So attempts to empower your internal strengths. Everyone should try to realize the real sense of aesthetic bliss and pleasure that remains inside us. Lead this life with positive approach. Many societies, engeos and universities are providing a lot of awareness programs, counseling sessions in this regards. Even educated people are attending various FDPs on universal human values and ethics. People are feeling the requirement of it. Many TV Channels are providing preaching series. A lot of motivational videos have been transferred daily through WhatsApp, Twitter and Instagram.

\section{CONCLUSION}

A number of literary contributions have been donated by the literary experts with the sublime goal to bring the drastic changes and to disseminate the sensation and awakening in society. The emergence of the ethical society is undoubtedly possible if every individual develops a good insight into the personality. The purgation of the inner self is the progression of purification of the society. The objective of such works of prolific writers is to fetch the attention of the readers towards the engrossed problems existing ever and creating problems in the way of success.Solutionseekers acknowledge the solutions lying in their selves and put the steps to reform. If the ample efforts are done, all the issues can easily be controlled. People should follow the path of universal human values and ethics in which the solution of all problems are there. Really the work of art is just like a lighted house that always enlightens the people for right path.

\section{REFERENCES}

Anand, Mulk Raj. (2003) Untouchable. Pune: Mehta Publishing House, Print.

Bhabani Bhattacharya. (1967) A Goddess Named Gold. Delhi: Hind Pocket Books Ltd, Print.

Bhattacharya, Bhabani. (1973) He Who Rides a Tiger. Delhi: Hind Pocket Books Ltd., Print.

Bhattacharya, Bhabani.( 1964) So Many Hungers. Bombay: Jaico Publishing House. Print.

Byrne Rhonda. (2006) Secret. Simon \& Schuster UK Ltd. Print.

James Vinson. (1972 ) 'Contemporary Novelists in the English Language' New York : St. Martin's press.

Kumar Priya. (2006) The Calling Unleash your True Self. Thomson Press, Print.

Sharma Robin. (2013) Magaliving.Jaico Publishing House, Mumbai. Print.

Sharma, K. K. (1979) "A Collection of Critical Essays, Bhabani Bhattacharya: His Vision and Themes." New Delhi: Abhinav Publications, Print.

Srivastava, K. Ramesh. (1982) "Perspective on BhabaniBhattacharya : A Critical Study."Amritsar : Guru Nanak Dev University. 